
Nur Khusniyah Indrawati (Indonesia)

\title{
Macro and Micro Determinants of Stock Return Companies in LQ-45 Index
}

Article history:

Received: 2017-08-22

Revised: 2017-11-06

Accepted: 2018-04-08

\section{Rahmat Fajar Basarda, Moeljadi Moeljadi, Nur Khusniyah Indrawati}

Department of Management Faculty of Economics and Business Brawijaya University Jl. M.T. Haryono No.165 Malang, 65145, Indonesia

Corresponding Author:

Rahmat Fajar Basarda:

Tel. +62 341551396

Fax +62 341553834

E-mail: rahmatfajarasus@gmail.com

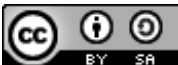

This is an open access article under the CC-BY-SA license

\begin{abstract}
The purpose of this study is to analyze the influence of solvability ratio, market ratio, inflation and interest rate on stock return of company LQ-45 listed in Indonesia Stock Exchange. The population of this study is the companies included in the LQ-45 index in the listing on the Indonesia Stock Exchange during the period 2015-2016 amounted to 90 companies. Data analysis in this research used multiple regression. The results showed that the variable solvabilities proxied with debt to equity ratio have a negative and significant effect on stock returns. The market ratio variable is proxied by price to book value have the positive and significant effect on stock return. The market ratio variable is proxied by price earnings ratio has the positive and significant effect on stock return. This means that any increase in the percentage of market value proxied by price earnings ratio will increase stock return. Inflation variable has a negative and significant effect on stock return. This means any increase in inflation will reduce the stock return, and interest rate variables have a positive and significant effect on stock returns.
\end{abstract}

Keywords: Inflation; Interest Rate; Market Ratio; Solvability Ratio; Stock Return

JEL Classification: D04; E44; G11

Citation: Basarda, R. F., Moeljadi, M., \& Indrawati, N. K. (2018). Macro and micro determinants of stock return companies in LQ-45 Index. Jurnal Keuangan dan Perbankan, 22(2), 310-320. https://doi.org/10.26905/jkdp.v22i2.1439.

\begin{abstract}
Abstrak
Tujuan penelitian ini menganalisis pengaruh rasio solvabilitias, rasio pasar, inflasi, dan suku bunga terhadap return saham perusahaan $L Q-45$ yang terdaftar di Bursa Efek Indonesia. Populasi dari penelitian ini adalah perusahaan yang termasuk ke dalam indeks LQ-45 yang ada di listing di Bursa Efek Indonesia selama periode 2015-2016 berjumlah 90 perusahaan. Analisis data dalam penelitian ini menggunakan regresi berganda. Hasil penelitian menunjukkan bahwa variabel solvabilitias diproksikan dengan debt to equity ratio berpengaruh negatif dan signifikan terhadap return saham. Variabel rasio pasar diproksikan dengan price to book value berpengaruh positif dan signifikan terhadap return saham. Variabel rasio pasar diproksikan dengan price earnings ratio berpengaruh positif dan signifikan terhadap return saham. Artinya setiap kenaikan presentase nilai pasar diproksikan dengan price earnings ratio akan meningkatkan return saham. Variabel inflasi berpengaruh negatif dan signifikan terhadap return saham. Artinya setiap kenaikan inflasi akan menurunkan return saham dan variabel suku bunga berpengaruh positif dan signifikan terhadap return saham.
\end{abstract}

Kata Kunci: Inflasi; Suku Bunga; Rasio Pasar; Rasio Solvabilitias; dan Return Saham 


\section{Macro and Micro Determinants of Stock Return Companies in LQ-45 Index}

Rahmat Fajar Basarda, Moeljadi Moeljadi , Nur Khusniyah Indrawati

The capital market has a big role for the economy of a country because it runs two functions at once, economic function and financial function. The capital market is a call to have an economic function because the capital market provides facilities that bring together two interests those who have excess funds or parties who will invest funds (investors) and parties that require funds such as companies (issuer).

LQ-45 shares are liquid stocks with high market capitalization, high trading frequency, growth prospects, and good financial condition, not fluctuating. Objectively selected by IDX and is a safe stock owned because the fundamental performance of the stock is good, so regarding risk group LQ-45 stock has the lowest risk than other stocks. Price fluctuations in the LQ-45 stock group tend to be smooth making the return from capital gains not as high as in the stock group experiencing significant price fluctuations. The growth value of LQ-45 index price index for 2014-2016 period indicates that in 2014 LQ45 stock price index is $898.581,2015$ is 792.033 , and in 2016 is 767.904. The results indicate that the LQ45 stock price index from 2014-2016 has decreased, this condition indicates that although LQ-45 stock is a good performing group, there is still uncertainty about the return received by the investor that appears from the fluctuation of stock return shown by the decline in stock prices.

Investors who will invest by buying shares in the capital market will analyze the company in advance so that investments made can provide profit (return). Return of shares is one of the factors that motivate investors to invest and is also a reward for the courage investors bear the risk of investing in it. From the company side, improving financial performance is considered a positive signal about the company's growth in the future, because it is interpreted as a profit to be obtained from investment decisions taken by the company. Although there cannot always be interdependent with investment decisions, funding and dividends in the company's financial management policy (Purnamasari, Kurniawati, \& Silvi, 2009).

There are several factors that influence stock return, both macro, and microeconomics. Macro factors exist both economic and non-economic. Macroeconomic factors are detailed in several economic variables, such as inflation, interest rates, exchange rates, foreign exchange, economic growth rates, international fuel prices, and regional stock indexes. Non-economic macro factors include domestic political events, social events, legal events, and international political events. Meanwhile, microeconomic factors are detailed in several financial ratios.

Solvency ratio is a ratio that indicates the company's assets ability to pay its long-term and short-term liabilities. Analyzing the financial statements from the solvency side can affect investor expectations that ultimately affect the index movement. Solvency ratios can be measured by debt to equity ratio (DER) reflecting the ability of the company to fulfill all its obligations indicated by what part of its capital is used to pay the debt. DER also provides guarantees about how much company debt secured its capital. DER will affect the company performance and cause the appreciation and depreciation of stock prices. The use of debt will make the risk borne by the shareholder's will increases. When there is an increase in debt amount in absolute, it will decrease company solvency level, which will have an impact on the decline in the value (return) of the company's stock. The study on the effect of DER on stock returns are performed by Sari \& Hutagaol (2009), and Firmansyah (2016) found evidence that DER influences stock returns. The different results are shown by Yarnest (2010), Afinindy \& Budiyanto (2017), and Wijaya (2017) found evidence that DER does not affect stock returns.

In addition to solvency ratios, other ratios that affect stock returns are market ratios. It used to measure the value of stocks proxied with price book value and price earnings ratio. Per share book value or price to book value (PBV). Market to book or 
PBV is the market ratio used to measure the stock performance market prices on the stock book value. The higher the PBV ratio of a company indicates, the higher the investor's assessment of the company. If the stock market price increases then the capital gain (actual return) of the stock also increases. This is because the actual return is the difference between the stock prices of the current period with the previous stock price. The results of the study on the effect of PBV on stock returns were performed by Sharma (2011), Srinivasan (2012), Malhotra \& Tandon (2013), and Almumani (2014) concluded that book value per share had a significant impact on stock return. Different results are shown by Khairi (2012), Kurniawati, Sari, \& Dewi (2012), and Yarnest (2012) states that PBV has an insignificant effect on stock returns.

Another ratio that affects stock return is price earnings ratio (PER). It can provide investors with information about past company performance and prospects. PER information indicates the amount of rupiah to be paid by an investor to earn one rupiah of company earnings. PER indicates the price of each one of the company's Rupiah earnings. In addition, it is also a measure of the company's stock relative price (Tandelilin, 2010). The PER ratio reflects the company's profit growth. The higher this ratio, will higher the profit growth expected by the investor.

Companies with high PER indicate companies have low risk, growth from high expected dividends and companies expected to have average growth with high dividend payout. Research on the effect of PER on stock price is done by Stella (2009), Sia \& Tjun (2011), Srinivasan (2012), Zuliarni (2012), and Rahmi, Arfan \& Jalaluddin (2013), concluded that PER effect on stock return. Different results shown by an empirical study conducted by Carlo (2014) concluded that PER does not affect the stock return.

In addition to microeconomic factors, macroeconomic factors can contribute to stock returns. According to Halim (2013), prudence in investing should be a concern for investment risks can be mini- mized and get the expected return, therefore investment decision not only requires information about the condition of the company but also the economic conditions of a country. Investors need to verify the macroeconomic conditions in the form of macroeconomic factors in investing in public companies in BEI, due to the strong relationship between macroeconomic environment conditions and performance in the capital market (Tandelilin, 2010). This is due to the overall macroeconomic conditions will affect the economic activities of society, entrepreneurs, investors and company performance (Halim, 2013).

Inflation is the prices tend to increase in general and continuously. Inflation can be sorted between permanent and temporary. The rate of core inflation is the rate of inflation caused by the increasing pressure of demand on goods and services (aggregate demand) in the economy. High inflation rates usually occur due to overheated economic conditions.

Nugroho (2008), Dwita \& Rahmidani (2012), Triaryati (2014), and Karim (2015), concluded that inflation has a negative and significant effect on stock returns. The negative relationship between inflation with the stock return because of inflation news will impact on the stock return because high inflation will decrease the profitability of company so that company stock return will be affected. Different results shown by Kurniadi (2013) found that the inflation rate did not affect the stock return.

In addition to inflation, macroeconomic factors that can be contributed to stock return are SBI rates. The interest rate is the amount of money paid in return for the use of borrowed debt. For banks, interest is the highest income component. From the total income received by the bank, most of it is obtained from interest on the loan. High-interest rates can lead to high volumes of community savings (Koostanto, 2013). The higher interest rates offered by banks encourage people to save more. Conversely, low-interest rates, both lending rates, and 


\section{Macro and Micro Determinants of Stock Return Companies in LQ-45 Index}

Rahmat Fajar Basarda, Moeljadi Moeljadi , Nur Khusniyah Indrawati

savings rates will have a decrease in the desire of the public to save, while for the company this condition is very profitable because the company can take credit to increase capital or investment with low-interest rates. Thus, interest rates will have a negative impact on stock returns logically (Koostanto, 2013).

An increase in interest rates will be very influential for capital market participants. The fluctuating and tend to increase SBI interest rates will affect the movement of the real sector reflected by the movement of stock returns. Due to rising interest rates, the owners of capital will prefer to invest their money in the bank rather than investing in stocks. Hancocks (2010) and Satoto \& Budiwati (2013) concluded that interest rates have a positive effect on stock returns. Different results shown by Koostanto (2013) and Mudji \& Rahayu (2003) indicate that the interest rate has a negative effect on stock returns.

The diversity of previous research results related to microeconomic variables such as debt equity ratio, price to book value and price earnings ratio and macroeconomy such as inflation and interest rate in influencing stock return, this study aims to examine the influence of solvability ratio, market ratio, inflation and the interest rate on the return of LQ-45 shares listed in Indonesia Stock Exchange (IDX).

\section{HYPOTHESES DEVELOPMENT}

DER reflects the company's ability to fulfill all its obligations indicated by what part of its own capital is used to repay debt. It also provides guarantees about how much debt the company secured its own capital. DER will affect the performance of the company and cause the appreciation and depreciation of stock prices. Sari \& Hutagaol (2009) and Firmansyah (2016) found evidence that DER affects stock returns. Based on the result of empirical study this research hypothesis as follows:
$\mathrm{H}_{1}$ : debt to equity ratio significant effect on stock return

PBV is the market ratio used to measure the stock market performance prices on the book value of a stock. Sharma (2011), Srinivasan (2012), Malhotra \& Tandon (2013), and Almumani (2014) concluded that book value per share has a significant impact on stock returns. Based on the results of empirical studies the research hypothesis is as follows:

$\mathrm{H}_{2}$ : price book value has a significant effect on stock return

PER can provide investors with information about past company performance and future prospects. PER information indicates the amount of rupiah to be paid by an investor to earn one rupiah of company earnings. Stella (2009), Sia \& Tjun (2011), Srinivasan (2012), Zuliarni, (2012), and Rahmi, Arfan, \& Jalaluddin (2013), concluded that price is earning ratio effect on stock prices. Based on the results of empirical studies the research hypothesis is as follows:

$\mathrm{H}_{3}$ : price earnings ratio has a significant effect on stock return

The higher inflation will lower the company profitability level. The decline in company profits is bad information for traders on the stock market causing a decline in stock prices in the company. Dwita \& Rahmidani (2012) and Karim (2015), concluded that inflation has a negative and significant effect on stock returns. Triaryati (2014) concludes that the negative relationship between inflation and stock return on inflation news will have an impact on the stock return because high inflation will decrease the company profitability so that the stock return will be affected. Based on the results of empirical studies the research hypothesis is as follows: $\mathrm{H}_{4}$ : inflation has a significant effect on stock return 
The interest rate is the amount of money paid in return for the use of borrowed debt. The higher interest rates offered by banks encourage people to save more. Conversely, low-interest rates, both lending rates, and savings rates will have a decrease in the desire of the public to save, while for the company this condition is very profitable because the company can take credit to increase capital or investment with low-interest rates. Thus, interest rates will have a negative impact on stock returns logically. Hancocks (2010) and Satoto \& Budiwati (2013) concluded that interest rates have a positive effect on stock returns. Different results shown by Mudji \& Rahayu (2003) and Koostanto (2013), they showed that interest rates have a negative effect on stock returns. Based on the results of empirical studies the research hypothesis is as follows:

$\mathrm{H}_{5}$ : interest rate has a significant effect on stock return

\section{METHODS}

The analysis unit in this study is 90 companies included in the LQ-45 index in the listing on the IDX for the period 2015-2016, with the following criteria: (1) the company listed on the Stock Exchange and entered in LQ-45 in a row from the period 2015-2016; and (2) issuance of financial statements as of December 31 continuously during the study period. Sampling is done by saturated sampling method.

The operational variable definition is a research element that tells how to measure a variable that allows researchers to collect relevant data for that variable. The variables in the study are presented in Table 1.

The method used to determine the effect of debt to equity ratio, price to book value, price earnings ratio, inflation and interest rates on stock return used multiple regression analysis. Equation model in this research are:

$$
Y=a+b_{1} X_{1}+b_{2} X_{2}+b_{3} X_{3}+b_{4} X_{4}+b_{5} X_{5}+e
$$

Information:

Y: stock return

b: standardized coefficient beta

$\mathrm{X}_{1}$ : debt to equity ratio

$\mathrm{X}_{2}$ : price to book value

$\mathrm{X}_{3}$ : price earning ratio

$X_{4}$ : inflation

$\mathrm{X}_{5}$ : interest rate

e: error

Hypothesis test used to test the effect of debt equity ratio, price to book value, price earning ratio, inflation, and the interest rate on stock return. This hypothesis was tested based on $t$ value analysis, the result from multiple regression models. The hypothetical formula mathematically is as follows:

$\mathrm{H}_{0}: \beta=0$, means that debt equity ratio, price to book value, price earning ratio, inflation and interest rate do not have a significant influence on stock return and $\mathrm{i}=1$, $2,3,5$

$H_{a}: \beta \neq 0, \quad$ means debt equity ratio, price to book value, price earning ratio, inflation and interest rate have a significant influence on stock return and $i=1,2,3,4$

Where the significance level is $\mathrm{a}=5$ percent and with degree of freedom $(\mathrm{k})$ and $(\mathrm{n}-\mathrm{k})$ where $\mathrm{n}$ is the number of observations and $\mathrm{k}$ is the independent variable. Then the $\mathrm{t}$-statistic is defined as follows:

$t-$ statistic $=\frac{\beta_{i}}{S_{e} \beta_{i}}$

Information:

$\beta_{\mathrm{i}} \quad=$ regression coefficient

$\mathrm{S}_{\mathrm{e}} \beta_{\mathrm{i}}=$ standard error regression coefficients 


\section{Macro and Micro Determinants of Stock Return Companies in LQ-45 Index}

Rahmat Fajar Basarda, Moeljadi Moeljadi , Nur Khusniyah Indrawati

Based on the significance level $\alpha=5$ percent, if $\mathrm{t}$-statistic $>\mathrm{t}$-table then $\mathrm{H}_{\mathrm{o}}$ is rejected, and $\mathrm{H}_{\mathrm{a}}$ accepted or if the probability value (Sig.) $\mathrm{T}<5$ percent then $\mathrm{H}_{\mathrm{o}}$ rejected and $\mathrm{H}_{\mathrm{a}}$ accepted. It means that the debt equity ratio, price to book value, price earnings ratio, inflation, and interest rates have a significant effect on the return of LQ-45 company's shares listed on the IDX.

\section{RESULTS}

Multiple linear regression analysis is used to see the effect of whether there was the influence of solvabilities variables proxy with debt to equity ratio, market value proxies' premises price book value and price earnings ratio, inflation, and interest rate to stock return. The results of multiple linear regression analysis were performed with Statistical

Table 1. Operational Definition and Variable Measurement

\begin{tabular}{|c|c|c|}
\hline Variable & Definition & Measurement \\
\hline \multicolumn{3}{|c|}{ Dependent Variables } \\
\hline Stock returns & $\begin{array}{l}\text { Return on investment within a certain period. The } \\
\text { return consists of capital gain (loss) which is the } \\
\text { deviation in profit (loss) from the current share price } \\
\text { with the share price of the past period. The traded } \\
\text { stock price is used to calculate the actual return. }\end{array}$ & $R_{i t}=\left[\frac{P_{i t}-p_{i t-1}}{P_{i t-1}}\right]$ \\
\hline \multicolumn{3}{|c|}{ Independent Variable } \\
\hline \multirow{2}{*}{$\begin{array}{l}\text { Solvency/ } \\
\text { Leverage Ratio }\end{array}$} & \multirow[b]{2}{*}{$\begin{array}{l}\text { The ratio used to measure how far the company's } \\
\text { assets are financed by debt. It means how much debt } \\
\text { burden is borne by the company compared to its } \\
\text { assets. Proxy solvency ratio is the Debt Equity Ratio } \\
\text { which shows the relationship between the number of } \\
\text { long-term loans granted by the creditors with the } \\
\text { amount of equity capital provided by the owners of } \\
\text { the company. }\end{array}$} & Long Term Debt \\
\hline & & {$[\overline{\text { StockHolders Equity }}$} \\
\hline \multirow[t]{5}{*}{ Market Ratio } & \multirow{3}{*}{$\begin{array}{l}\text { Market ratios are useful ratios to measure a company's } \\
\text { ability to provide returns or rewards to the investor, } \\
\text { especially investors in the stock market. Market ratio } \\
\text { proxy is: }\end{array}$} & Price per share \\
\hline & & $\overline{\text { Book value per share }}$ \\
\hline & & Stock Price \\
\hline & $\begin{array}{l}\text { Price to Book Value is one of the market ratios to } \\
\text { measure stock market price performance on the book } \\
\text { value }\end{array}$ & Earningpershare \\
\hline & $\begin{array}{l}\text { Price earning ratio shows the comparison between the } \\
\text { stock price in the market or the offered prime price } \\
\text { compared to the revenue received. }\end{array}$ & \\
\hline Inflation & $\begin{array}{l}\text { Inflation is represented by the inflation sensitivity } \\
\text { which is the rate of the influence of inflation changes } \\
\text { on the firm in a certain period. Inflation sensitivity can } \\
\text { be seen from the amount of beta coefficient }(\beta) \\
\text { inflation of each company. }\end{array}$ & $\begin{array}{l}Y_{i}=a+\beta_{i} \text { Inflation }+e \\
Y_{i} \text { is the company's net sales, while } \beta i \text { is the } \\
\text { inflation sensitivity. }\end{array}$ \\
\hline Interest rate & $\begin{array}{l}\text { Interest rates are represented by the interest rate } \\
\text { sensitivity which is the rate of the influence of interest } \\
\text { rate changes on the firm within a certain period. } \\
\text { Interest rate sensitivity is seen from the amount of } \\
\text { beta coefficient }(\beta \mathrm{i}) \text { interest rate of each company. }\end{array}$ & $\begin{array}{l}Y_{i}=a+\beta_{i} \text { Interest rate }+e \\
Y_{i} \text { is the company's net sales, while } \beta \mathrm{i} \text { is the } \\
\text { Interest Rate }\end{array}$ \\
\hline
\end{tabular}


Package for Social Science (SPSS) 17.0 for windows, as shown in Table 2.

$F$ test in this research is used to test the accuracy or research model significance. Based on the research results obtained value of $F$ is 5.258 with a probability value of 0.000 and significant at alpha (a) 5 percent (0.05). It means that solvabilities are proxied by DER, the market ratio is proxied by PBV and PER, and inflation and interest rates deserve to explain stock returns. The prediction of the regression model $\left(R^{2}\right)$ formed in this test is 0.262 . These results indicate that the solvability is proxied by DER, the market ratio is proxied by PBV and PER, inflation and interest rates have a contribution to stock return is 26.2 percent, while the remaining 73.8 percent is influenced by other variables outside the model.

Based on Table 2 it can be explained that the value of $\mathrm{t}$-statistic for the variable solvabilities proxied with the debt to equity ratio $\left(X_{1}\right)$ is -3.858 with coefficient of -0.488 and has a significance value 0.000 smaller than the statistical significance at $\alpha=5$ percent $\mathrm{H}_{0}$ which means that the variable solvabilities proxied with debt to equity ratio has a negative and significant effect on stock return.

The value of $t$-statistic for the market ratio variables proxies with the price book value $\left(X_{2}\right)$ is 2.056 with the coefficient value 0.246 and has a significance value 0.043 smaller than the statistical significance at $\alpha=5$ percent, thus rejecting $\mathrm{H}_{0}$ which means that the ratio of market ratio proxies with price book value has a positive and significant effect on stock return.

The value of $\mathrm{t}$-statistic for the market ratio variables proxies with price earnings ratio $\left(X_{3}\right)$ is 2.344 with coefficient value 0.283 and has a significance value is 0.022 smaller than the statistical significance at $\alpha=5$ percent, thus rejecting $\mathrm{H}_{0}$ which means that the market ratio variable proxy with price earnings ratio has a positive and significant effect on stock return.

The value of $t$-statistic for the inflation variable $\left(X_{4}\right)$ is -3.064 with the coefficient -0.344 and has a significance value is 0.003 is smaller than the statistical significance at $\alpha=5$ percent, thus rejecting $\mathrm{H}_{0}$ which means that the inflation variable has a negative and significant effect on return stock.

The value of $\mathrm{t}$-statistic for the interest rate variable $\left(X_{5}\right)$ is 2.846 with the coefficient value 0.335 and has a significance value is 0.006 smaller than the statistical significance at $\alpha=5$ percent, thus rejecting $\mathrm{H}_{0}$ which means that the variable interest rate has a positive and significant effect on return stock.

\section{DISCUSSION}

\section{The Effect of Debt to Equity Ratio on Stock Return}

Based on the results of the inferential statistical analysis, there was evidence that the solvency

Table 2. Recapitulation of Results of Multiple Linear Regression Analysis

\begin{tabular}{lcccc}
\hline \multicolumn{1}{c}{ Research Variables } & $\begin{array}{c}\text { Standardized } \\
\text { Coefficients }\end{array}$ & $\mathbf{t}$ & Prob. & Description \\
\hline Debt to equity ratio & -0.488 & -3.858 & 0.000 & Significant \\
Price book value & 0.246 & 2.056 & 0.043 & Significant \\
Price earnings ratio & 0,283 & 2.344 & 0.022 & Significant \\
Inflation & -0.344 & -3.064 & 0.003 & Significant \\
Interest Rate & 0.335 & 2.846 & 0.006 & \\
R : 0.512 & & & & \\
R Square: 0.262 & & & & \\
F value : 5.258 & & & & \\
Prob. F : 0.000 & & & & \\
\hline
\end{tabular}


proxied by DER had a negative effect on stock return. In other words, any increase in DER percentage will decrease the stock return. The results of the analysis also showed that DER could give an idea of the capital structure owned by the company so that it can be seen the level of unpaid risk of debt. It also showed the level of company debt, companies with large debts have large debt costs as well. This is a burden for companies that can lower the level of investor confidence. Investors tend to avoid stocks with high DERs. When there was an increase in debt in absolute, it will decrease company solvency level, which will have an impact on the decline in the value of the company's return.

DER is the proxy used to measure company performance from solvency aspect. DER is the ratio used to assess debt with equity and can provide general guidance on the feasibility and financial risk of the company. Investors tend to avoid stocks that have high DER value because high DER values reflect relatively high company risk. The results of this study reinforce previous studies conducted by Sari \& Hutagaol (2009) found evidence that DER influences stock returns.

\section{The Effect of Price Book Value on Stock Return}

Based on the results of inferential statistical analysis obtained the evidence that the variable market ratio proxies with price book value have a positive effect on stock return. PBV which the ratio between stock prices to book value. If a company has a PBV above $1(>1)$, then the stock price of the company is valued higher than the book value that describes the company's performance is getting better in the investors perspective. Thus the higher the PBV then the stock return will increase. If the stock market price increases then capital gains from the stock also increase. This is due to the actual return of capital gains is the difference between the stock prices of the current period with the stock price of the previous period.
For investors, PBV of a company is one of the considerations in determining its investment strategy. The high company PBV ratio will be able to generate high returns for investors. With noticed the variable PBV information's is expected investors get the return in accordance with the expected, in addition to the risks faced. The results of this review reinforce previous studies conducted by Sharma (2011), Srinivasan (2012), Malhotra \& Tandon (2013) and Almumani (2014) concluded that book value per share has a significant impact on stock returns.

\section{The Effect of Price Earnings Ratio of Stock Return}

The analysis of financial ratios in this study was also seen from the market valuation ratio as illustrated by Brigham \& Houston (2009) which market ratios as the ratio that correlates the firm's stock price to its earnings, cash flows, and book value per share. This ratio can provide management indication of what investors were thinking about past performance and prospects. This market value ratio was proxied by PER. Based on the results of inferential statistical analysis obtained evidence that market ratio variables proxies with price earnings ratio have a positive effect on stock returns. PER is a comparison between the market price of a stock and the EPS of the stock concerned. PER is a ratio that compares the price per share, which are usually circulated by earnings per share.

The higher PER indicated that the stock price was rated higher by an investor on the earnings per share so that the higher PER also shows more expensive the stock on the earnings per share. Firms with high PER usually have a high growth rate opportunity, which causes an investor's interest to buy a company's stock that can increase stock prices. The increase in stock prices will be responded positively by investors because they will get capital gain which is one component of stock return, therefore indicat- 
ing that PER will have a positive influence on stock return. The results of this study reinforce previous studies conducted by Stella (2009), Sia \& Tjun (2011), Srinivasan (2012), Zuliarni, (2012), Rahmi, Arfan, \& Jalaluddin (2013), concluded that PER effect on stock return.

\section{The Effect of Inflation on Stock Return}

Based on the results of inferential statistical analysis obtained evidence that inflation has a negative effect on stock returns. Inflation showed a condition whereby an increase in general price flows whose measurement may use a change in the consumer price index (CPI). The increase of inflation rate did not favor by the capital market because it will increase production cost which has a negative impact on price and income. Also, the high inflation rate indicated that the investment risk is quite large because high inflation will reduce the rate of return from investors. Tandelilin (2010), stated that inflation is a tendency to increase the price of the products as a whole. High inflation reduced the level of real income that investors get. Conversely, if a country's inflation rate declines, therefore, it is a positive signal for investors related to declining purchasing power risk and risk of declining real incomes. The results of this study reinforce the previous review conducted by Triaryati (2014) concluded that negative relationship between inflation with stock returns due to inflation information would impact on stock returns because high inflation will reduce the company profitability so that it will effect on the company stock return. Nugroho (2008), Dwita \& Rahmidani (2012), and Karim (2015), in their research, concluded that inflation has a negative and significant effect on stock return.

\section{The Effect of Interest Rate on Stock Return}

Based on the results of inferential statistical analysis obtained the evidence that interest rates have a positive effect on stock returns. The interest rate is the money paid in return for the use of bor- rowed debt. An increase in interest rates will cause a decrease in stock returns and vice versa. In the face of an increase in interest rates, shareholders will hold their shares until the interest rate returns at a normal level. Conversely, if long-term interest rates increase therefore shareholders tend to sell their shares because of high selling prices. The change in the interest rate causes a change in the interest rate imposed on security. Rising interest rates causes in investors being able to withdraw their investments in capital markets and move their investments in savings or deposits. The results of this study reinforce the previous review conducted by Mudji \& Rahayu (2003) and Koostanto (2013), they showed that the interest rate has a negative effect on stock returns.

An important finding of this research that micro-economic factors as factors that can be controlled company, an indicator of the growth of financial performance to generate profits. The better micro-economic factors, investors are increasingly retaining ownership in the future. If it happens continuously (sustainable), therefore it can raise the stock price and increase the stock return. On the other hand, macroeconomic factors contribute in creating investor preferences to invest in capital markets. Positive changes in this factor, prompting investors to maintain their investment so that the impact on the increase in stock prices and raise the stock return.

\section{CONCLUSION AND SUGGESTIONS}

\section{Conclusion}

This study examines the effect of solvabilities variables proxied with debt to equity ratio, market value is proxied by price book value and price earnings ratio, inflation and interest rate on stock return. Based on the results of the research found that solvabilities proxied with debt to equity ratio have a negative and significant effect on stock return; it means that every increase of the percentage of solvability in proxy with debt to equity ratio will de- 


\section{Macro and Micro Determinants of Stock Return Companies in LQ-45 Index}

Rahmat Fajar Basarda, Moeljadi Moeljadi , Nur Khusniyah Indrawati

crease stock return. Market ratios proxies with price book value have a positive and significant effect on stock return, it means that every increase of market value percentage proxies with price book value will increase stock return. Market ratios proxies with price earnings ratio have a positive and significant effect on stock return; it means that every increase of market value percentage proxies with price earnings ratio will increase stock return. Inflation has a negative and significant effect on stock return. It means any increase in inflation will reduce the stock return. Interest rates have a positive and significant effect on stock returns; it means that any increase in interest rates will increase stock returns

\section{Suggestions}

In the operation implementation, the company should reduce the proportion of funding from debt to reduce financial distress, because the financing of the company's debt causes financial distress and agency cost greater than the tax savings from debt interest expense. Consequently, the company is very vulnerable to economic turmoil and causing stock prices down which impacted on the acquisition of stock returns. Investors in making investment decisions need to consider market ratios proxied with price book value and price earnings ratio, it is important to assess what the estimated potential revenue is acceptable. Investors should consider inflation information and interest rates to be used in predicting the price of the stock to make the right decision with its investment. Future research needs to develop this research by extending research samples in manufacturing industries which vulnerable to macroeconomic changes.

\section{REFERENCES}

Afinindy, I., \& Budiyanto. (2017). Pengaruh DER, PER, dan ROE terhadap return saham perusahaan telekomunikasi. Jurnal Ilmu dan Riset Manajemen, 6(6), 1-15.

Almumani, M. A. (2014). Determinants of equity share prices of the listed banks in Amman stock exchange: Quantitative approach. International Journal of Business and Social Science, 5(1), 91-104.

Brigham, E. F., \& Houston, J. F. (2009). Fundamentals of Financial Management. 12th Edition. Mason: South-Western Cengage Learning.

Carlo, M. A. (2014). Pengaruh return on equity, dividend payout ratio, dan price to earnings ratio pada return saham. E-Jurnal
Akuntansi Universitas Udayana, 7(1), 150-164.

Dwita \& Rahmidani. (2012). Pengaruh inflasi, suku bunga, dan nilai tukar terhadap return saham sektor restoran hotel dan pariwisata. Jurnal Kajian Manajemen Bisnis, 1(1).

Firmansyah, I. (2016). Determinan return saham syariah dengan risiko sistematis sebagai variabel mediasi. Jurnal Keuangan dan Perbankan, 20(3), 358-368.

Halim, A. (2013). Analisis Investasi. Edisi Kedua. Jakarta: Salemba Empat.

Hancocks, R. L. (2010). An analysis of the influence of domestic macroeconomic variables on the performance of South African stock market sectoral indices. Thesis. Master of Commerce (Financial Markets) Rhodes University.
Karim, A. (2015). Pengaruh faktor internal dan eksternal terhadap return saham di BEI. Jurnal ekonomi dan Manajemen, 30(1).

Khairi, M. S. (2012). Analisis pengaruh karakteristik perusahaan terhadap return saham syariah yang tergabung di Jakarta Islamic Index pada periode 20082011. Jurnal Manajemen dan Akuntansi Terapan, 1(1), 1-10.

Koostanto, H. B. (2013). Pengaruh inflasi, suku bunga, nilai tukar, dan PDB terhadap perubahan tingkat pengembalian saham perusahaan yang terdaftar pada Bursa Efek Indonesia. Skripsi. Fakultas Ekonomi dan Manajemen Institut Pertanian Bogor.

Kurniadi, R. (2013). Analisis pengaruh nilai tukar, suku bunga SBI, dan jumlah uang beredar terhadap harga saham sektor 
properti di Bursa Efek Indonesia (BEI) Periode 2006 - 2011. Skripsi. Fakultas Ekonomi dan Bisnis Universitas Islam Negeri Syarif Hidayatullah Jakarta.

Kurniawati, S. L., Sari, L. P., \& Dewi, N. H. U. (2012). Faktor penentu return saham dengan price to book value sebagai variabel moderasi di Bursa Efek Indonesia. Jurnal Keuangan dan Perbankan, 16(3), 382-389.

Malhotra, N., \& Tandon, K. (2013). Determinants of stock prices: Empirical evidence from NSE 100 Companies. International Journal of Research in Management \& Technology, 3(3), 89-95.

Mudji, U., \& Rahayu, M. (2003). Peranan profitabilitas, suku bunga, inflasi, dan nilai tukar dalam mempengaruhi pasar modal Indonesia selama krisis ekonomi. Jurnal Manajemen $\mathcal{E}$ Kewirausahaan, 5(2), 123-131.

Nugroho, H. (2008). Analisis pengaruh inflasi, suku bunga, kurs, dan jumlah uang beredar terhadap Indeks LQ-45. Universitas Diponegoro Semarang.

Purnamasari, L., Kurniawati, S. L., \& Silvi, M. (2009). Interdependensi antara keputusan, investasi, keputusan pendanaan, dan keputusan dividen. Jurnal Keuangan dan Perbankan, 13(1), 106-119.
Rahmi, A., Arfan, M., \& Jalaluddin. (2013). Pengaruh faktor-faktor fundamental dan risiko sistematik terhadap harga saham (Studi pada perusahaan manufaktur yang terdaftar di Bursa Efek Indonesia periode 20072009). Jurnal Akuntansi Pascasarjana Universitas Syiah Kuala, 2(2), 1-15.

Sari, L. A., \& Hutagaol, Y. (2009). Debt to equity ratio, degree of operating leverage, stock beta and stock returns of food and beverages companies on the Indonesian Stock Exchange. Journal of Applied Finance and Accounting, 2(2), 1-13.

Satoto, S. H., \& Budiwati, S. (2013). Pergerakan harga saham akibat perubahan nilai tukar, inflasi, tingkat bunga, dan gross domestic product. Jurnal Keuangan dan Perbankan, 17(3), 407-416.

Sharma, S. (2011). Determinants of equity share prices in India. Journal of Arts, Science, \& Commerce, 2(4), 51-60.

Sia, V. L. R., \& Tjun, T. L. (2011). Pengaruh current ratio, earnings per share, dan price earnings ratio terhadap harga saham. Jurnal Akuntansi, 3(2), 136-158.

Srinivasan, P. (2012). Determinants of equity share prices in India: A panel data approach. The Romanian Economic Journal, 46(6), 205-228.

Stella. (2009). Pengaruh PER, DER, ROA, dan PBV terhadap harga pasar saham. Jurnal Bisnis dan Akuntansi, 11(2), 97-106.

Tandelilin, E. (2010). Portofolio dan Investasi (Teori dan Aplikasi). Edisi Pertama. Yogyakarta: Kanisius.

Triaryati, N. (2014). Hubungan return saham dan inflasi di Indonesia. Jurnal Keuangan dan Perbankan, 18(3), 434-442.

Wijaya, R. (2017). Kinerja keuangan dan ukuran perusahaan terhadap harga saham dengan kebijakan dividen sebagai variabel intervening. Jurnal Keuangan dan Perbankan, 21(3), 459- 472 .

Yarnest. (2012). Rasio keuangan pengukur kinerja perusahaan dan dampaknya terhadap ekspektasi return saham. Jurnal Keuangan dan Perbankan, 16(1), 99-11.

Zuliarni, S. (2012). Pengaruh kinerja keuangan terhadap harga saham pada perusahaan mining and mining service di Bursa Efek Indonesia (BEI). Junal Aplikasi Bisnis, 3(1). 